Review of Income and Wealth

Series 44, Number 4, December 1998

\title{
THE SENSITIVITY OF INTERNATIONAL POVERTY COMPARISONS
}

\author{
By McKinley L. Blackburn \\ University of South Carolina
}

\begin{abstract}
Using data from the Luxembourg Income Study, I study the sensitivity of cross-national income poverty comparisons to the method in which poverty is measured. Absolute poverty comparisons that keep the purchasing power at the poverty line constant across countries lead to conclusions that differ from relative poverty comparisons in which the real value of the poverty line varies with average income. The absolute poverty ranking of countries also varies as the real value of the poverty line is lowered. Cross-national differences in household characteristics are largely irrelevant in explaining poverty differences.
\end{abstract}

Consider two simplified characterizations of how economically-advanced countries approach problems associated with individuals with low incomes. One type of country provides limited income support to low-income individuals through government transfers, with virtually no support to able individuals judged to be appropriately self-sufficient. The second type of country provides income support to any individual with low income, and may consider one goal of government policy to reduce the inequality of incomes that may arise in the absence of government. The income support system of the U.S. is generally characterized as following along the lines of the first type of country (for example, see Ellwood and Summers, 1986). Many of the welfare states of Western Europe, such as Sweden and Germany, are thought of as following the second approach (see the discussion in Mitchell, 1991). One might expect the second type of country to exhibit lower levels of income poverty, since this is a stated goal of government policy in these countries. The authors of several recent cross-national studies of poverty have concluded that this is indeed the case (e.g. see Buhmann et al., 1988; Smeeding et al., 1990; and Mitchell, 1991).

What does it mean for poverty to be higher in one country than in another? Despite considerable effort devoted by social scientists in constructing and defending various measures of poverty, no consensus has been reached on an appropriate metric for this concept. In fact, there is general disagreement over whether the state of being poor should be defined on the basis of some absolute needs standard, or on the basis of "needs" that change as the average level of well-being increases (see Atkinson, 1983; Blackburn, 1990). Given this lack of consensus, conclusions from comparisons of poverty in different countries can be

Nore: Helpful comments were provided by Timothy Smeeding, and by seminar participants at Syracuse University, University of Pittsburgh, and the Luxembourg Income Study Workshop. A version of the paper "International Comparisons of Income Poverty and Extreme Income Poverty" previously circulated as a LIS working paper. 
quite fragile if there is insufficient exploration of the sensitivity of comparisons to the way in which poverty is operationalized. ${ }^{1}$

In what follows, I attempt to gauge the sensitivity of poverty comparisons across countries to the manner in which poverty is measured. I proceed by establishing a set of "standard" poverty lines to use in measuring poverty. However, I also examine how the level of poverty would change if the poverty cutoffs were one-half the size of the standard poverty lines-a level I term "extreme" poverty. As discussed in Section II, this is the beginning of the type of poverty comparison suggested by Atkinson (1987). I make comparisons of poverty in Australia, Canada, the U.S., and several advanced economies in Western Europe.

I use the household-level income data available in the database constructed by the Luxembourg Income Study (LIS), which provides income data from various years from 1979 to 1987 . These data have been used in several recent comparisons of poverty across countries. ${ }^{2}$ The bulk of previous research using the LIS data has used measures of relative poverty, in the sense that poverty lines are constructed as a given percentage of the median level of income. An important difference in the current study is that I consider how poverty comparisons would differ if absolute poverty lines-reflecting constant purchasing power across countries-were used instead. This latter manner of setting poverty lines is similar to that used by the U.S. Census Bureau in its construction of poverty rates at different points in time in the U.S. The results show that poverty comparisons can be very sensitive to whether a relative or absolute standard is used. Comparisons of absolute poverty are also sensitive to where the poverty line is fixed, so that cross-national comparisons using standard poverty rates can lead to different conclusions than comparisons using extreme poverty rates. I also examine the sensitivity of poverty comparisons to changes in other characteristics of the poverty measure, such as equivalence scales, and methods of purchasing power adjustment, but find much less sensitivity to these other choices.

Measures of poverty would be expected to differ across countries if factors related to poverty also differed across countries. For example, families in the U.S. are more commonly headed by an unmarried female than families in other countries I study. Since female-headed families are more poverty-prone in all countries, this difference in female headship rates can potentially explain higher poverty in the U.S. relative to other countries. An additional concern of this paper is quantifying the importance of demographic (age and household type) and labor supply differences across countries to differences in measures of absolute poverty.

\section{The LiS DATA}

The goal of the Luxembourg Income Study (LIS) is to gather and process household-level income data for a wide range of countries. Each of the country

\footnotetext{
${ }^{1}$ Such problems arise in measuring poverty on the basis of incomes only (as I do in this paper). Additional concerns are related to measuring economic well-being using income, rather than wealth, consumption, self-perceptions of poverty status, etc. One alternative to studying income poverty is to use more direct measures of consumption and living conditions; Mayer (1992) makes cross-national comparisons using this approach.

${ }^{2}$ See the references cited in Mitchell (1991).
} 
files in the LIS dataset comprise basic data from income surveys performed by statistical agencies in each of the individual countries. Information from these surveys have been provided to researchers at the Center for Population, Poverty, and Policy Studies, and the International Networks for Studies in Technology, Environment, Alternatives, and Development, both in Luxembourg. There, the data have been made as comparable as possible across the countries, given what is available on each individual country's survey. A more detailed history of the construction of the data is provided in Smeeding and Schmaus (1990).

There are currently over 75 different datasets that are part of LIS. Each dataset has information on annual income for a particular country in a particular year. In this paper, I analyze the available data for 19 of those country/year datasets. For eight of the countries-Australia, Canada, France, Germany, the Netherlands, Sweden, the U.K., and the U.S.- I am able to use data from two different years. ${ }^{3}$ For each of these countries, there is data from one year in the 1979-83 period, and from one year in the $1984-87$ period. I also include three other countries--Austria, Italy, and Luxembourg-for which there is income information only for one year.

The basic income-sharing unit in my analysis is (with some exceptions) the household. This choice was dictated by the inability to identify separate families within the same household in the data for many countries. ${ }^{4}$ However, in practice, household- and family-based poverty measures tend to be quite similar in those countries for which both can be calculated. The basic income measure that is used is "disposable income," which can be thought of as a measure of after-tax, after-transfer income. In most countries (the exceptions are Austria, Italy, and Luxembourg) I also have available measures of household income that are pretax, pre-transfer (referred to as "factor income") and that are pre-tax, post-transfer (referred to as "gross income"). Taxes are directly reported in most country's data, but have been imputed (by the LIS researchers) in those instances where they were not directly reported. Also, the U.S. data includes imputations of certain noncash benefits (food, housing, and medical benefits). All of the datasets suffer from income underreporting, though a limited analysis suggests that this underreporting may be similar across countries (Smeeding and Schmaus, 1990).

\section{Measuring Poverty}

Constructing a measure of income poverty requires at least three choices: one, the definition of income for any given individual; two, the level of income below which an individual is considered poor; and, three, the index used to represent the level of poverty for the society as a whole. There have been several suggestions for the appropriate handling of these decisions; in this section I briefly discuss the issues and detail how I will proceed. ${ }^{5}$

\footnotetext{
${ }^{3}$ The German data are for West Germany only.

${ }^{4}$ The Canadian data for 1981 have only the family unit available. Both Swedish datasets have available only the "tax unit," which treats all separate tax filers as an income unit (the income measure still comes from survey responses, not tax records). This leads to all unmarried adults (over the age of 18 ) being treated as separate units, even if they reside with their parents.

${ }^{5}$ See Atkinson (1987) for a more extensive discussion of these issues.
} 


\section{A. Defining an Individual's Level of Income}

Let $Y_{i}$ be the annual income of the $i$-th household (or other income sharing unit). Given that there is no information on how income is actually shared within the household, the conventional assumption is that the level of economic wellbeing (as reflected in annual income) is the same for all individuals in the household.

A given level of income is expected to represent a higher level of well-being the smaller is the number of individuals in the household. In the poverty measurement literature, this fact is generally referred to as the income "needs" being higher for larger households. A common method of handling these differences is to construct a set of equivalence scales, intended to reflect the extent to which income must increase as household size increases in order for well-being to remain constant. These equivalence scales consist of a set of numbers, $E_{i}$, one for each household; $E_{i}$ is equal to the ratio of income for the $i$-th household to income for some reference household, such that the level of well-being is the same in both households. $E_{i}$ can be thought of as the household size expressed as its equivalent in numbers of single-adult households, so that $Y_{i} / E_{i}$ represents income per equivalent adult (or "equivalent income").

$E$ could be allowed to depend on any of a number of characteristics of the household, but in this study I limit those characteristics to the number of adults $(A)$ and the number of children $(C)$. As in Cutler and Katz (1992), I use scales of the form

$$
E\left(A_{i}, C_{i}\right)=\left(A_{i}+k C_{i}\right)^{e} .
$$

The constant $e$ represents the extent to which there are economies of scale in income sharing; the smaller is $e$, the greater the extent of these economies. The constant $k$ allows the needs of children to differ from those of adults. Most researchers agree that $e$ should be greater than zero but less than one, but there is considerable disagreement over which part of that interval is most appropriate. Buhmann et al. (1988) suggest that $e \approx 0.75$ is typical of scales used by "expert analysts" wishing to count numbers of low-income individuals, and it is this choice ( $e=0.75$, along with $k=1$ ) that I primarily use in this paper. However, this choice is quite arbitrary, so I will also explore the sensitivity of measurements to changes in this choice.

\section{B. Setting the Poverty Lines}

Given that each individual can be assigned a level of income (associated with their household) that can be expressed in equivalent terms of an income received by a single adult, it is necessary only to set a poverty line for a single adult. Suppose that for some given country, this poverty line is $Z$. Then all individuals in the $i$-th household are poor if

$$
Y_{i} / E_{i} \leq Z \text {. }
$$

Otherwise, all individuals in the household are not poor. As noted above, I will consider the $i$-th household as "extremely" poor if the condition also holds when $Z / 2$ is used in place of $Z$ in equation (2). 
In this study, a poverty line must be chosen for each country/year dataset. One of two strategies are generally used in connecting the poverty lines over time or across countries. The first is to use a relative poverty standard, so that the poverty line for a given country in a given year depends on the average level of well-being in that country or that year. For example, the poverty line might be set at 50 percent of the median level of equivalent income in that country and year. With relative poverty, an increase in incomes by the same proportion for all households would not change the classification of any individuals as poor or not poor, though it would increase average income and, presumably, well-being. However, a decrease in the dispersion of incomes would tend to lower the number of individuals classified as poor.

The other strategy is to set poverty lines meant to have the same purchasing power in each country and year. This absolute poverty standard is commonly used in studying changes in poverty over time in a given country, where the poverty line is changed over time to reflect changes in some price index. In the present study, the situation is complicated by the need to compare the purchasing power of incomes in different countries' currencies. I use the OECD purchasing power parities for private consumption in constructing these absolute poverty lines. ${ }^{6}$ In particular, $Z_{t}^{C}$, the poverty line in country $c$ and year $t$, is calculated as

$$
Z_{t}^{C}=Z_{85}^{\mathrm{US}}\left(Z_{85}^{C} / Z_{85}^{\mathrm{US}}\right)\left(Z_{t}^{C} / Z_{85}^{C}\right),
$$

where the latter two ratios are of poverty lines with the same purchasing ability. The first term in parentheses represents the purchasing power parity of country $c$ 's currency in U.S. dollars in 1985, while the second term in parentheses reflects average price level changes over time within country $c .^{7}$

The set of absolute poverty lines are defined once $Z_{85}^{\mathrm{US}}$ is specified. For most of my calculations I will use the same poverty line, for a single-person household, as is used by the U.S. Census Bureau. ${ }^{8}$ This is $\$ 5,479$ in U.S. dollars for 1985. This choice is quite arbitrary. It leads to what most would consider to be high measured poverty in almost all countries. Atkinson (1987) has suggested exploring the sensitivity of poverty assignments to this choice by allowing poverty lines to vary over a range of possible values. I follow this suggestion by considering what measured poverty would be if the poverty lines were changed to be 75 percent, then 50 percent, and then 25 percent of the standard lines. ${ }^{9}$

${ }^{6}$ The purchasing power parities were constructed by the OECD using data on quality-adjusted prices in the various countries in 1985 . These price data are not available for other years, so the only manner in which to construct parities for these other years is to multiply by the ratio of price changes in the two countries between that year and 1985, which is what equation (3) does. The purchasing power parities are based on price indices that use a common basket of goods across countries. Unfortunately, this basket is for all consumers, and does not reflect differences in consumptions patterns between low-income and average households.

${ }^{7}$ Consumer price indices reported in International Monetary Fund (1991) are used in this adjustment. The adjustment factors for the combination of inflation and currency change are reported in the OECD column of the appendix table.

${ }^{8}$ The poverty lines I use for households of other sizes will differ from those of the Census Bureau, since different equivalence scales are used.

${ }^{9}$ The poverty index I primarily use is the headcount ratio, measured as the percentage of individuals in households below their poverty line. I also report the index (based on the squared coefficient of variation) suggested Foster, Greer, and Thorbecke (1984), which is designed to be sensitive to extremely low incomes. 


\section{Poverty Comparisons}

Before discussing measures of poverty derived from the LIS data, I present some descriptive statistics characterizing the income distributions in the countries studied.

TABLE 1

Means and Coefficients of Variation for AduUsted Household Income

\begin{tabular}{|c|c|c|c|c|c|c|c|}
\hline \multirow[b]{2}{*}{ Country } & \multirow[b]{2}{*}{ Year } & \multicolumn{3}{|c|}{ Mean $^{1}$} & \multicolumn{3}{|c|}{ Coeff. of Variation } \\
\hline & & FY & GY & DY & FY & GY & DY \\
\hline \multicolumn{8}{|l|}{$1979-83$} \\
\hline Australia & $1981-2$ & 8,769 & 9,635 & 7,559 & 0.79 & 0.67 & 0.55 \\
\hline Canada & 1981 & 11,660 & 12,780 & 10,836 & 0.74 & 0.64 & 0.58 \\
\hline France & 1979 & 6,223 & 7,786 & 7,105 & 1.60 & 1.26 & 0.81 \\
\hline Germany & 1981 & 8,070 & 9,722 & 7,409 & 0.78 & 0.56 & 0.51 \\
\hline Netherlands & 1983 & 7,565 & 9,408 & 6,236 & 0.92 & 0.68 & 0.59 \\
\hline Sweden & 1981 & 6,496 & 9,019 & 6,338 & 0.83 & 0.52 & 0.48 \\
\hline United Kingdom & 1979 & 6,977 & 8,332 & 6,708 & 0.77 & 0.58 & 0.53 \\
\hline United States & 1979 & 12,366 & 13,476 & 10,649 & 0.82 & 0.73 & 0.60 \\
\hline \multicolumn{8}{|l|}{$1984-87$} \\
\hline Australia & $1985-6$ & 9,107 & 10,000 & 7,703 & 0.93 & 0.79 & 0.75 \\
\hline Austria & 1987 & & & 7,452 & & & 0.42 \\
\hline Canada & 1987 & 12,357 & 13,778 & 11,199 & 0.77 & 0.65 & 0.57 \\
\hline France & 1984 & 6,361 & 8,247 & 7,538 & 1.28 & 0.97 & 0.76 \\
\hline Germany & 1984 & 8,014 & 9,672 & 7,375 & 0.90 & 0.66 & 0.62 \\
\hline Italy & 1986 & & & 6,473 & & & 0.71 \\
\hline Luxembourg & 1985 & & & 9,114 & & & 0.47 \\
\hline Netherlands & 1987 & 8,170 & 10,073 & 6,350 & 0.90 & 0.66 & 0.55 \\
\hline Sweden & 1987 & 7,121 & 9,961 & 6,692 & 0.90 & 0.57 & 0.53 \\
\hline United Kingdom & 1986 & 7,368 & 9,150 & 7,157 & 0.97 & 0.71 & 0.64 \\
\hline United States & 1986 & 13,485 & 14,686 & 11,555 & 0.90 & 0.80 & 0.68 \\
\hline
\end{tabular}

Note: Adjusted household income is income per equivalent adult in the household. Household incomes are weighted by the number of persons in the household, and by any household weight variables available on the parent survey. For countries without household designations, the averages are across either families or tax units (see Appendix Table A.1).

'The income abbreviations are: FY: factor income (wages and salaries plus property income). GY: gross income (factor income plus cash and some noncash transfers). DY: disposable income (gross income minus income and payroll taxes).

All means are expressed in 1985 U.S. dollars. See the text for discussion of conversion of other currencies to U.S. dollars.

Average income among individuals in each of the nineteen country/year datasets is reported in Table 1. The income for each individual is the equivalent income of that individual's household. All averages are adjusted (using OECD purchasing power parities) so as to be expressed in U.S. dollars in 1985. Three separate income measures are used: pre-tax, pre-transfer income (factor income); pre-tax, post-transfer income (gross income); and post-tax, post-transfer income (disposable income). ${ }^{10}$ The results suggest that average income is considerably higher in Canada and the U.S. than in Australia, or in the European countries included in the sample. Among these latter countries, average income is highest in Luxembourg, while average disposable income is roughly the same in the

\footnotetext{
${ }^{10}$ The primary taxes subtracted are income and payroll taxes.
} 
remainder of the countries. " For countries with two different years of data, the sample average disposable income increased from the 197983 period to the 1984 87 period in every country except Germany.

An index of dispersion for the three sources of income is also reported in Table 1. The statistics reported are coefficients of variation, a standard index of inequality. One advantage of the coefficient of variation over other indices is that it can be calculated when the sample includes incomes equal to zero for households with no factor income. The results suggest that factor income inequality is much higher in France than in the other countries, and appears to be lowest in Canada (among those countries with sufficient information to calculate factor income). The coefficients of variation for factor income in the U.S. do not appear to be much different from the European countries (other than France). The reduction in inequality from including transfers in income tends to be much larger in the European countries than in the U.S., Canada, or Australia. The dispersion in disposable income is highest in France, although the U.S., Italy, and Australia have higher levels of disposable income inequality than the other countries studied.

From $1979-83$ to $1984-87$, increases in the sample coefficients of variation for disposable income occurred in Australia, Germany, Sweden, the U.K., and the U.S., but not in Canada, France, and the Netherlands.

\section{A. Absolute Poverty Comparisons}

Headcount ratios for each of the three income definitions are reported in Table 2, using the "standard" poverty lines discussed in Section II. To gauge the extent to which sampling variation may contribute to cross-national differences in measured poverty, I also calculate standard errors for the poverty rates, treating both poverty status and household size as random variables. ${ }^{12}$

Standard poverty rates constructed using factor income show Canada and the U.S. to be the least poor among the countries studied; France is the most poor using this income definition. The other European countries (and Australia) exhibit poverty rates that tend to be at least 50 percent higher than those in Canada and the U.S. Standard errors for these poverty rates are fairly small; for a comparison of poverty rates in any two countries, a difference of 3 percentage points or more is statistically significant (at the 5 percent level). ${ }^{13}$ The poverty rates in all countries (and particularly in Germany, the Netherlands, and Sweden) are much smaller if gross income is used instead of factor income; these countries' gross-income poverty rates are close in magnitude to those of the U.S.

The preferred measure of income in calculating poverty rates is disposable income. Incorporating taxes in the income measure increases poverty rates in all

\footnotetext{
"These patterns across countries are essentially replicated in the per capita private consumption expenditure series provided in OECD (1989). The final two columns of the appendix table present this series, along with calculations of per capita disposable income from LIS. The correlation coefficient between the two series is 0.88 .

${ }^{12}$ The headcount ratios are calculated using any household weights that are available. See the appendix for details on how the standard errors are calculated.

${ }^{13}$ The standard error for the difference in poverty rates between Germany 1981 and Germany 1984 is 0.015 . The standard error for all other comparisons would be less than 0.015 .
} 
TABLE 2

Poverty Rates, with Various Definitions of Income

\begin{tabular}{lcccc}
\hline \hline & & \multicolumn{3}{c}{ Proportion Below Poverty Line' $^{1}$} \\
\cline { 5 - 5 } Country & Year & Factor Income & Gross Income & Disposable Income \\
\hline I979-83 & & & & \\
Australia & $1981-2$ & $0.329(0.005)$ & $0.274(0.004)$ & $0.366(0.005)$ \\
Canada & 1981 & $0.228(0.004)$ & $0.140(0.004)$ & $0.156(0.004)$ \\
France & 1979 & $0.550(0.006)$ & $0.407(0.007)$ & $0.425(0.007)$ \\
Germany & 1981 & $0.347(0.011)$ & $0.180(0.008)$ & $0.335(0.011)$ \\
Netherlands & 1983 & $0.405(0.008)$ & $0.232(0.007)$ & $0.521(0.009)$ \\
Sweden & 1981 & $0.452(0.007)$ & $0.174(0.006)$ & $0.390(0.007)$ \\
United Kingdom & 1979 & $0.427(0.007)$ & $0.314(0.006)$ & $0.432(0.007)$ \\
United States & 1979 & $0.250(0.005)$ & $0.175(0.004)$ & $0.201(0.004)$ \\
1984-87 & & & & \\
Australia & $1985-6$ & $0.340(0.006)$ & $0.282(0.006)$ & $0.384(0.007)$ \\
Austria & 1987 & & & $0.273(0.006)$ \\
Canada & 1987 & $0.226(0.005)$ & $0.118(0.005)$ & $0.136(0.005)$ \\
France & 1984 & $0.538(0.006)$ & $0.359(0.006)$ & $0.371(0.006)$ \\
Germany & 1984 & $0.376(0.010)$ & $0.220(0.010)$ & $0.344(0.010)$ \\
Italy & 1986 & & & $0.492(0.008)$ \\
Luxembourg & 1985 & & & $0.180(0.011)$ \\
Netherlands & 1987 & $0.381(0.009)$ & $0.193(0.008)$ & $0.500(0.010)$ \\
Sweden & 1987 & $0.425(0.007)$ & $0.142(0.005)$ & $0.340(0.006)$ \\
United Kingdom & 1986 & $0.451(0.007)$ & $0.312(0.006)$ & $0.411(0.007)$ \\
United States & 1986 & $0.254(0.005)$ & $0.178(0.005)$ & $0.208(0.005)$ \\
\hline
\end{tabular}

Note: The reported statistics are the proportion of individuals with equivalent household income less than $\$ 5479$ (in 1985 U.S. dollars).

'The numbers in parentheses are standard errors for the country's poverty rate estimate.

countries, but the increase is most substantial in Germany, the Netherlands, and Sweden. The increase is particularly large in the Netherlands; roughly 50 percent of the population has disposable income that is lower than the income at the 20th percentile in the U.S. Disposable income poverty is substantially higher in all of the European countries (and Australia) compared to the U.S., the primary exception being Luxembourg (which in 1987 had a lower poverty rate than the U.S. in 1986). ${ }^{14}$ Measured poverty appears to be lower in Canada than in any of the other countries.

Poverty rates using various proportions of the standard poverty lines are reported in Table 3 . Simply reducing the poverty lines by 25 percent (to 75 percent of the standard lines) leads to much lower poverty rates in most of the European countries. Compared to the U.S., measured poverty is higher in Australia, France, Italy, the Netherlands, and the U.K., but about the same in Austria, Germany,

\footnotetext{
${ }^{14}$ As noted earlier, these comparisons may be less persuasive when they involve Sweden, since the income-sharing unit is defined differently in the Swedish data. However, Swedish poverty rates still tend to be higher than in Canada, Luxembourg, and the U.S. when attention is focused on groups whose measured poverty is not likely to be affected by the difference in income units (e.g. married couples with no children); these results are presented in Section IV of the paper.
} 
TABLE 3

Poverty Rates at Different Proportions of the Standard Poverty Lines (Income Measure: Disposable Income)

\begin{tabular}{|c|c|c|c|c|c|c|}
\hline \multirow[b]{2}{*}{ Country } & \multirow[b]{2}{*}{ Year } & \multicolumn{4}{|c|}{ Percent of Standard Poverty Line } & \multirow{2}{*}{$\begin{array}{c}\text { FGT } \\
\text { Measure }^{\prime}\end{array}$} \\
\hline & & 100 & 75 & 50 & 25 & \\
\hline \multicolumn{7}{|l|}{$1979-83$} \\
\hline Australia & $1981-2$ & 0.37 & 0.18 & 0.06 & 0.02 & 0.049 \\
\hline Canada & 1981 & 0.16 & 0.08 & 0.03 & 0.01 & 0.031 \\
\hline France & 1979 & 0.43 & 0.22 & 0.06 & 0.02 & 0.066 \\
\hline Germany & 1981 & 0.33 & 0.13 & 0.02 & 0.00 & 0.027 \\
\hline Netherlands & 1983 & 0.52 & 0.26 & 0.07 & 0.04 & 0.083 \\
\hline Sweden & 1981 & 0.39 & 0.14 & 0.04 & 0.01 & 0.162 \\
\hline United Kingdom & 1979 & 0.43 & 0.22 & 0.05 & 0.01 & 0.052 \\
\hline United States & 1979 & 0.20 & 0.12 & 0.05 & 0.02 & 0.042 \\
\hline \multicolumn{7}{|l|}{$1984-87$} \\
\hline Australia & $1985-6$ & 0.38 & 0.20 & 0.07 & 0.03 & 0.130 \\
\hline Austria & 1987 & 0.27 & 0.10 & 0.02 & 0.00 & 0.019 \\
\hline Canada & 1987 & 0.14 & 0.07 & 0.03 & 0.01 & 0.024 \\
\hline France & 1984 & 0.37 & 0.18 & 0.05 & 0.02 & 0.068 \\
\hline Germany & 1984 & 0.33 & 0.14 & 0.03 & 0.00 & 0.028 \\
\hline Italy & 1986 & 0.49 & 0.30 & 0.11 & 0.02 & 0.074 \\
\hline Luxembourg & 1985 & 0.18 & 0.05 & 0.01 & 0.00 & 0.011 \\
\hline Netherlands & 1987 & 0.50 & 0.24 & 0.06 & 0.02 & 0.065 \\
\hline Sweden & 1987 & 0.34 & 0.13 & 0.05 & 0.01 & 0.065 \\
\hline United Kingdom & 1986 & 0.41 & 0.22 & 0.07 & 0.03 & 0.084 \\
\hline United States & 1986 & 0.21 & 0.13 & 0.06 & 0.02 & 0.046 \\
\hline
\end{tabular}

Note: The "standard" poverty line is that used in constructing the poverty rates in Table 2 . The reported poverty rates are calculated using the designated proportion of the standard poverty line.

${ }^{1}$ This is the poverty measure suggested by Foster, Greer, and Thorbecke (1984).

and Sweden. Only Italy clearly has a higher level of poverty than the U.S. if the "extreme poverty" lines are used (the 50 percent column), while several countries (including Germany) may have lower poverty rates. The standard and extreme poverty rate pairs are plotted in Figure 1. The plot suggests a positive, though not precise, relation between the two rates (the correlation coefficient is 0.66 ). The two U.S points suggest relatively high extreme poverty rates given the level of the standard rates (the correlation coefficient is 0.76 if these two points are dropped). ${ }^{15}$ If the poverty lines are set at 25 percent of the standard lines, calculated poverty is negligible in all of the countries. For most countries, there is little evidence of a change in poverty in the early 1980s. France, Sweden, and the U.K. experienced statistically significant declines in measured standard poverty rates over this period, while Australia was the only country with an increase that was statistically significant. The U.K. is the only instance in which a sample extreme poverty rate changed by more than one percentage point.

The absolute poverty comparisons are clearly sensitive to where the poverty lines are anchored. Much of this has to do with the level of income at which taxes seem to play a significant role in reducing disposable income. In many European

\footnotetext{
${ }^{15}$ The FGT index also refiects the tendency for the poor in the U.S. to be more likely to be extremely poor; the index is much lower in Austria, Germany, and Luxembourg than in the U.S. although none of these countries have clearly lower standard poverty rates.
} 


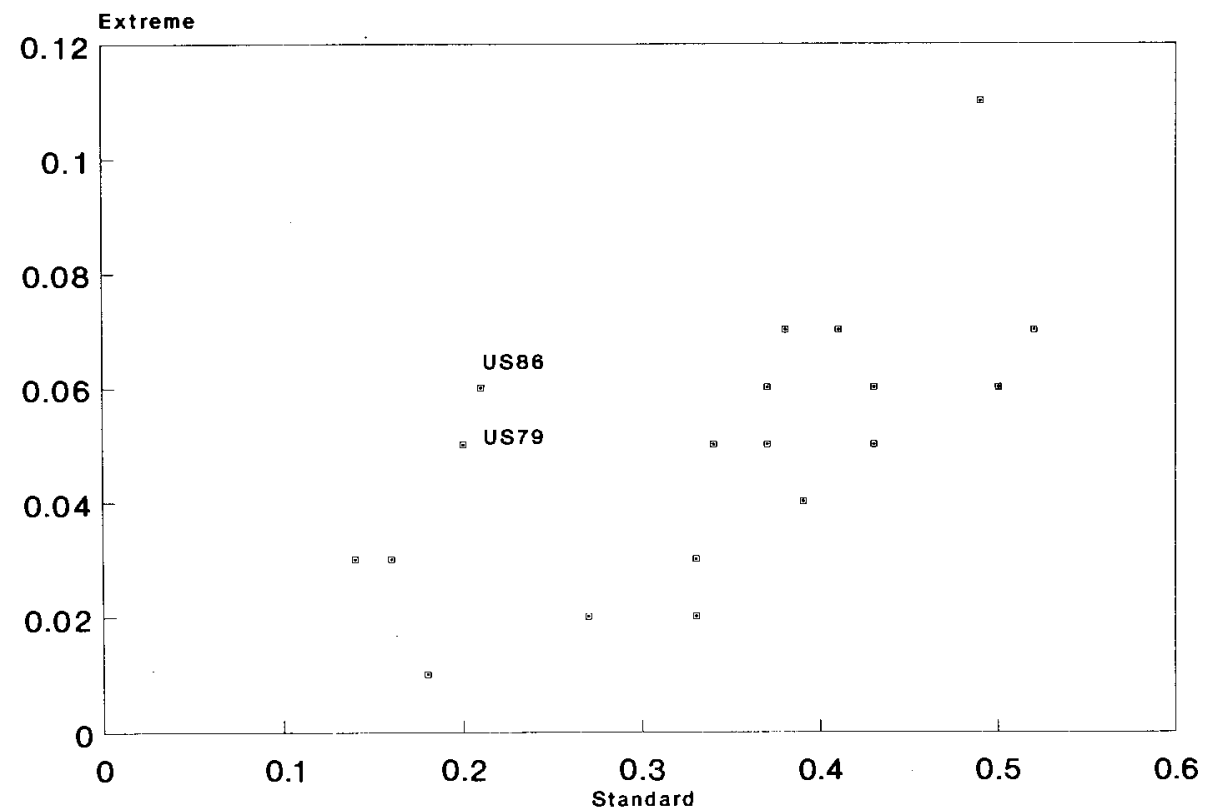

Figure 1. Standard and Extreme Poverty Rates

countries, taxes have a major effect at around equivalent income levels of $\$ 4,000$ $\$ 5,000$, while individuals at these same levels in Canada and the U.S. are not paying substantial amounts of tax. At lower income levels, taxes play a minor role in reducing disposable income in all countries, leading to lower poverty rates in most European countries compared to the U.S.

\section{B. Relative Poverty Comparisons}

Most studies of cross-national differences in poverty have used a relative definition of poverty status. This is particularly true of the literature that has made use of the LIS data. ${ }^{16}$ This research has tended to conclude that poverty in the U.S. is relatively high. My absolute poverty comparisons suggest, if anything, the opposite conclusion. Given this difference, I believe it important to repeat the kind of relative poverty comparisons made by earlier researchers.

The general approach in measuring relative poverty has been to assign poverty lines as a certain percentage of median income. I follow this procedure, first using 50 percent, and then 25 percent, of median equivalent income in setting the poverty lines. A clear advantage of studying relative poverty is that purchasing

\footnotetext{
${ }^{16}$ Two exceptions are Smeeding and Torrey (1988), who study child poverty only, and Hanratty and Blank (1990), who make poverty comparisons between the U.S. and Canada only. Smeeding and Torrey did find that the U.S. had higher absolute poverty (among children) than the European countries they considered, but they did not consider poverty for the population as a whole. Smeeding and Torrey also only had available purchasing power parities based on a 1980 price survey that is considered not as complete as the 1985 study used to construct parities for this study.
} 
TABLE 4

Relative Poverty Rates

\begin{tabular}{|c|c|c|c|c|c|c|c|}
\hline \multirow{2}{*}{$\begin{array}{l}\text { Poverty Line' } \\
\text { Country }\end{array}$} & \multirow[b]{2}{*}{ Year } & \multicolumn{3}{|c|}{$50 \%$ of Median } & \multicolumn{3}{|c|}{$25 \%$ of Median } \\
\hline & & FY & GY & DY & FY & GY & DY \\
\hline \multicolumn{8}{|l|}{$\overline{1979-83}$} \\
\hline Australia & $1981-2$ & 0.23 & 0.15 & 0.10 & 0.16 & 0.03 & 0.02 \\
\hline Canada & 1981 & 0.21 & 0.15 & 0.12 & 0.12 & 0.03 & 0.02 \\
\hline France & 1979 & 0.25 & 0.09 & 0.08 & 0.16 & 0.02 & 0.02 \\
\hline Germany & 1981 & 0.22 & 0.07 & 0.05 & 0.17 & 0.01 & 0.01 \\
\hline Netherlands & 1983 & 0.27 & 0.09 & 0.07 & 0.22 & 0.05 & 0.04 \\
\hline Sweden & 1981 & 0.28 & 0.06 & 0.05 & 0.20 & 0.02 & 0.01 \\
\hline United Kingdom & 1979 & 0.24 & 0.12 & 0.07 & 0.17 & 0.01 & 0.01 \\
\hline United States & 1979 & 0.24 & 0.19 & 0.16 & 0.14 & 0.05 & 0.04 \\
\hline \multicolumn{8}{|l|}{$1984-87$} \\
\hline Australia & $1985-6$ & 0.24 & 0.16 & 0.11 & 0.17 & 0.03 & 0.03 \\
\hline Austria & 1987 & & & 0.04 & & & 0.00 \\
\hline Canada & 1987 & 0.22 & 0.14 & 0.11 & 0.13 & 0.03 & 0.02 \\
\hline France & 1984 & 0.26 & 0.09 & 0.09 & 0.17 & 0.02 & 0.02 \\
\hline Germany & 1984 & 0.26 & 0.09 & 0.06 & 0.20 & 0.01 & 0.01 \\
\hline Italy & 1986 & & & 0.11 & & & 0.02 \\
\hline Luxembourg & 1985 & & & 0.05 & & & 0.01 \\
\hline Netherlands & 1987 & 0.25 & 0.07 & 0.06 & 0.21 & 0.02 & 0.02 \\
\hline Sweden & 1987 & 0.30 & 0.08 & 0.06 & 0.22 & 0.02 & 0.02 \\
\hline United Kingdom & 1986 & 0.31 & 0.14 & 0.10 & 0.24 & 0.03 & 0.03 \\
\hline United States & 1986 & 0.25 & 0.20 & 0.18 & 0.16 & 0.07 & 0.05 \\
\hline
\end{tabular}

Note: Poverty lines are set as a percentage of a country's median equivalent income. Income abbreviations are the same as in Table 1.

${ }^{1}$ Separate medians are used for each of the three income types.

power parities and price indices are unnecessary. ${ }^{17}$ Table 4 reports these poverty rates for each of the three income definitions. All of the countries have fairly similar factor income poverty rates when the poverty lines are set at 50 percent of the median. At 25 percent of the median, factor income poverty tends to be higher in Germany, the Netherlands, Sweden, and the U.K. (in 1986) than in other countries. This is at least partially due to the higher percentage of households with no earners in those countries (see Section IV). With gross income, poverty rates tend to be higher in the U.K. and its former colonies (at 50 percent of the median), and highest in the U.S. This pattern holds when using disposable income, although now Italy's poverty rate is quite high among European countries. Poverty rates for gross income and disposable income tend to be very low if the poverty line is set at 25 percent of the median; the primary outliers are the higher poverty rates in the U.S., and the Netherlands in 1983.

These calculations support the conclusions of earlier researchers that the U.S. exhibits high levels of poverty relative to advanced European economies, when relative poverty comparisons are made. They also support the contention that the choice between relative and absolute poverty concepts is important to how one

\footnotetext{
${ }^{17}$ Information on relative price changes within a country could be useful in measuring relative poverty. However, as pointed out in $\mathrm{n} .6$, this information is not available for this analysis.
} 


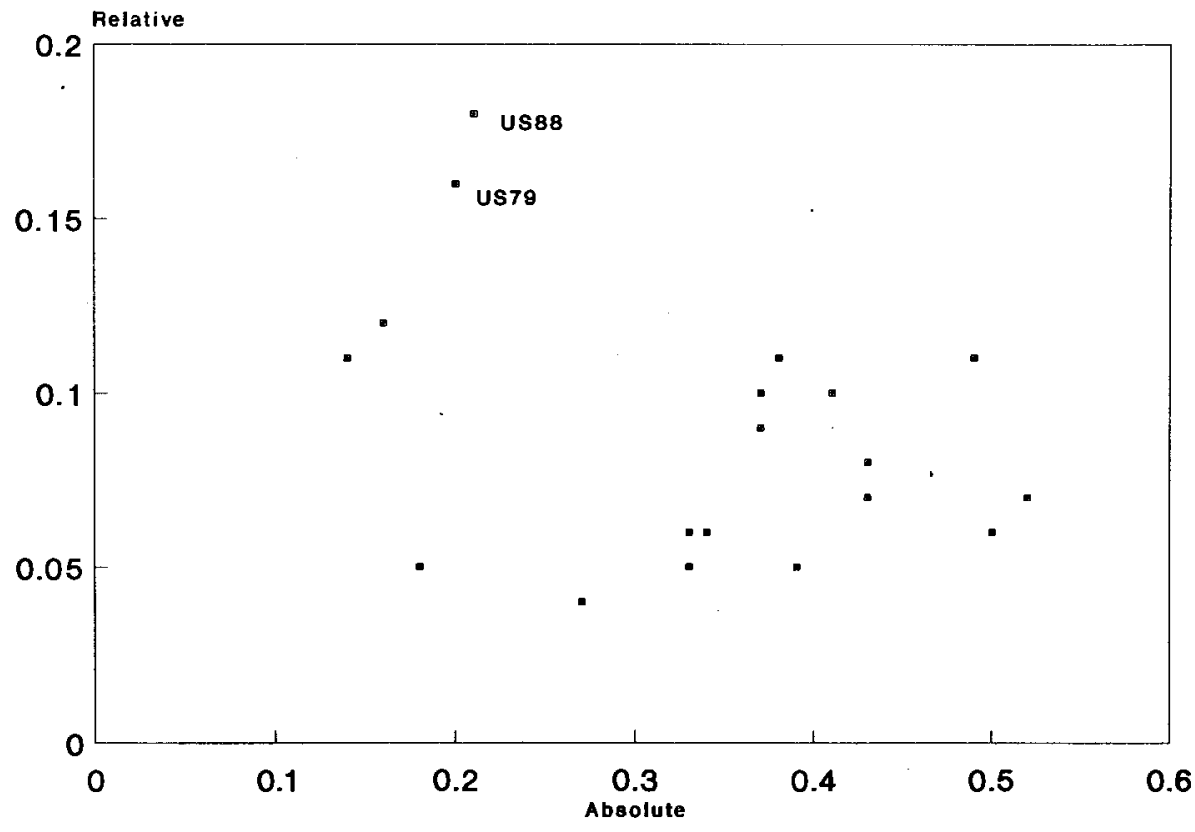

Figure 2. Absolute and Relative Poverty Rates

views poverty differences across countries. This importance is illustrated by plotting the absolute and relative poverty rates from the nineteen country/year datasets (see Figure 2). ${ }^{18}$ If anything, there appears to be a negative relationship between these two measures among these countries (or no relationship, if the two points for the U.S. are ignored). ${ }^{19}$

\section{Sensitivity of Results}

How sensitive are the estimated poverty rates to changes in how poverty is measured? The basic conclusions of the analysis of absolute poverty are not particularly sensitive to changes in equivalence scales or purchasing power parities, though some of the country rankings are changed when these changes are made.

In Figure 3, I plot the standard poverty rates from Table 3 (called the "base poverty rates") against standard poverty rates using alternative choices for the equivalence scale parameters in equation (1). Two alternatives are considered: one, $k=1, e=0.25$, which assumes much greater economies of scale within the household; and, two, $k=0.4, e=0.5,{ }^{20}$ assuming an intermediate degree of economies, and that children require less than adults. Figures $3 \mathrm{a}$ and $3 \mathrm{~b}$ maintain the

\footnotetext{
${ }^{18}$ These are the standard poverty rates for disposable income from Table 3 , and the disposable income poverty rates at 50 percent of median income from Table 4.

${ }^{19}$ The correlation coefficient is -0.36 , but -0.09 if the U.S. points are omitted.

${ }^{20}$ This latter set of scales was used in Cutler and Katz (1992).
} 
poverty line for a single-person household at the same value as in earlier calculations. This does tend to lower the value of the poverty line considerably for larger households, especially when $e=0.25$, so I also changed the equivalence scales keeping the poverty line for a more average household size (three persons) constant (see Figures $3 \mathrm{c}$ and $3 \mathrm{~d}$ ). The poverty rates using these alternative equivalence scales are clearly positively correlated with the Table 3 poverty rates, although this correlation is weaker when the change in equivalence scale reduces the average poverty line (as in Figures $3 a$ and $3 b$ ). This is not surprising, since many of the countries with high standard poverty lines have substantial declines in measured poverty as the value of the poverty lines are reduced (see Table 3). Similar results are obtained when the equivalence scales for the extreme poverty rates are changed (see Figure 4), although the correlations with the Table 3 rates are smaller than in Figure 3.

I also explored the sensitivity of the absolute poverty rates to changes in the purchasing power parities (PPPs) used to change countries' 1985 currency value to 1985 U.S. dollars. As an alternative to the OECD PPPs, I use the 1985 purchasing power parities for consumption provided by Summers and Heston (1991). I keep the real value of the poverty line constant at $\$ 5,439$ (in $1985 \$$ US), but change other countries nominal poverty lines to reflect the Summers and Heston PPPs. These alternative exchange factors, reported in the appendix table, tend to be close to the OECD factors. ${ }^{21}$ The standard and extreme poverty rates using the two sets of PPPs are plotted in Figure 5 (the base poverty rates use the OECD PPPs). ${ }^{22}$ The estimated poverty rates are also very similar using either set of purchasing power parities, although Australia's poverty rates are somewhat lower when the Summers-Heston PPPs are used. In general, the conclusions seem robust to changes in the PPPs and the equivalence scales.

\section{Household Characteristics and Cross-National Differences}

Some types of individuals are more poverty prone than others. For example, in the U.S. households headed by an unmarried woman with children are more likely to have incomes below the U.S. poverty line than households headed by a married couple (e.g., see Garfinkel and McLanahan, 1986). Changes in household characteristics have been studied as a potential explanation of movements over time in poverty rates in the U.S. ${ }^{23}$ In this section, I consider the extent to which cross-national differences in household characteristics can account for observed differences in standard and extreme poverty.

Table 5 reports percentages of the population in various demographic/earner categories in each of the country/year datasets. In all of the countries, the most prevalent household type is the married couple, with more individuals in married couple households with children than in married couples without children. At

\footnotetext{
${ }^{21}$ The two sets of PPPs appear to be based on the same price data (from the United Nations International Comparison Program), although they involve different methods of aggregating this data into a price index. The actual Summers-Heston PPPs that I use are from the supplementary tables (for the Penn World Table Mark 5) to the Summers and Heston article.

${ }_{22}$ The equivalence scales use $k=1, e=0.75$.

${ }^{23} \mathrm{I}$ perform an analysis of this type in Blackburn (1990).
} 

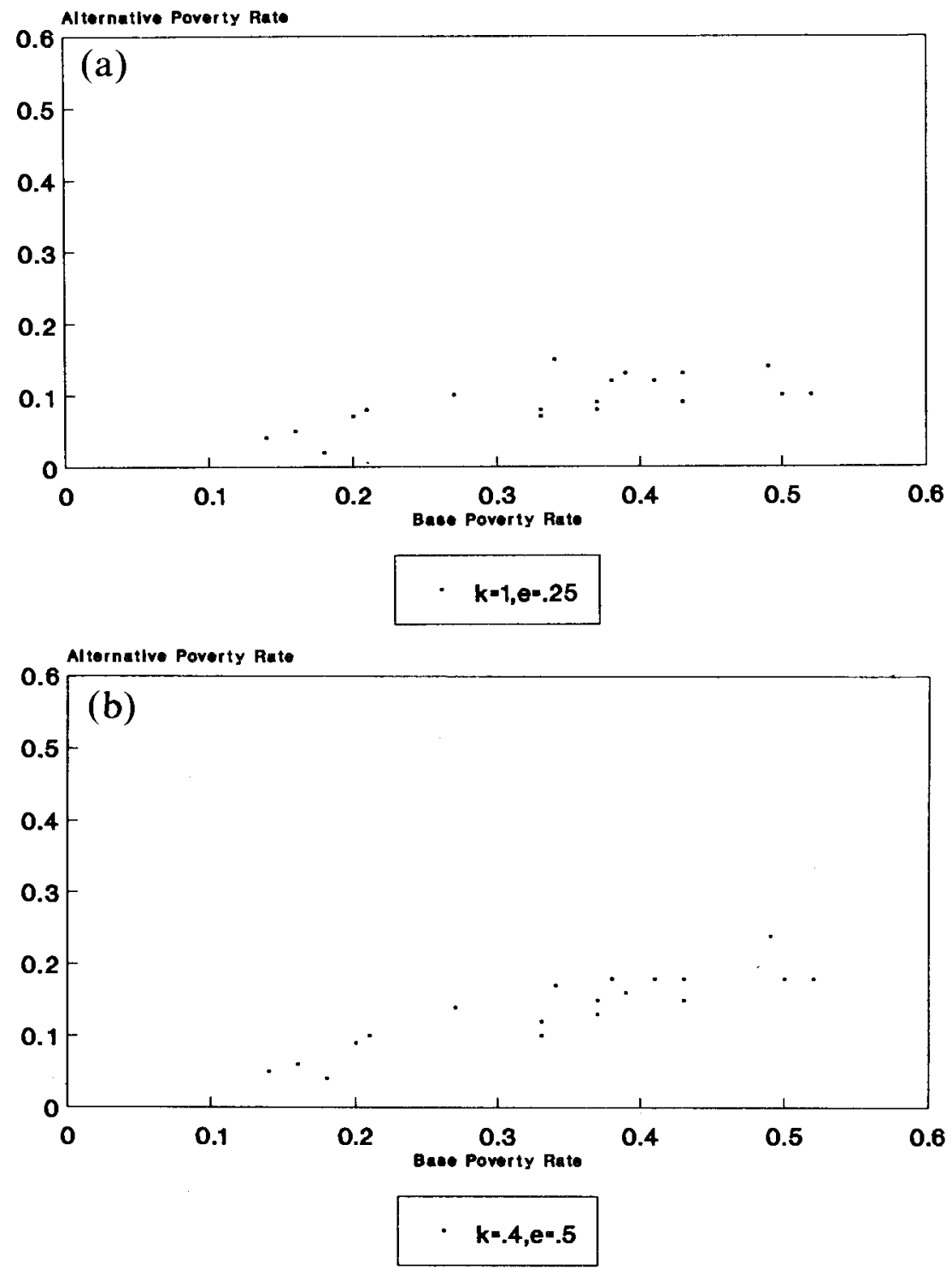

\section{Note: Conotant poverty llne tor
alng lo-pergon hovethote}

Figure 3. Standard Poverty, Alternative Equivalence Scales

least 79 percent of individuals live in married couple households in all countries except the U.S. (74 percent), Austria (70 percent), and Sweden (67 percent). ${ }^{24}$ The

${ }^{24}$ Sweden's low percentage is at least partly due to the income-tax unit definition. The incometax unit counts all adults living with their parents as not living in a married couple household, while they would be counted as living in a married couple household in all other countries. However, it would appear that Sweden would have a low married couple percentage even if the household were the unit of analysis, since only 8 to 10 percent of individuals in Sweden live in households with a head under age 25 (assuming most adults living with their parents are under the age of 25). 

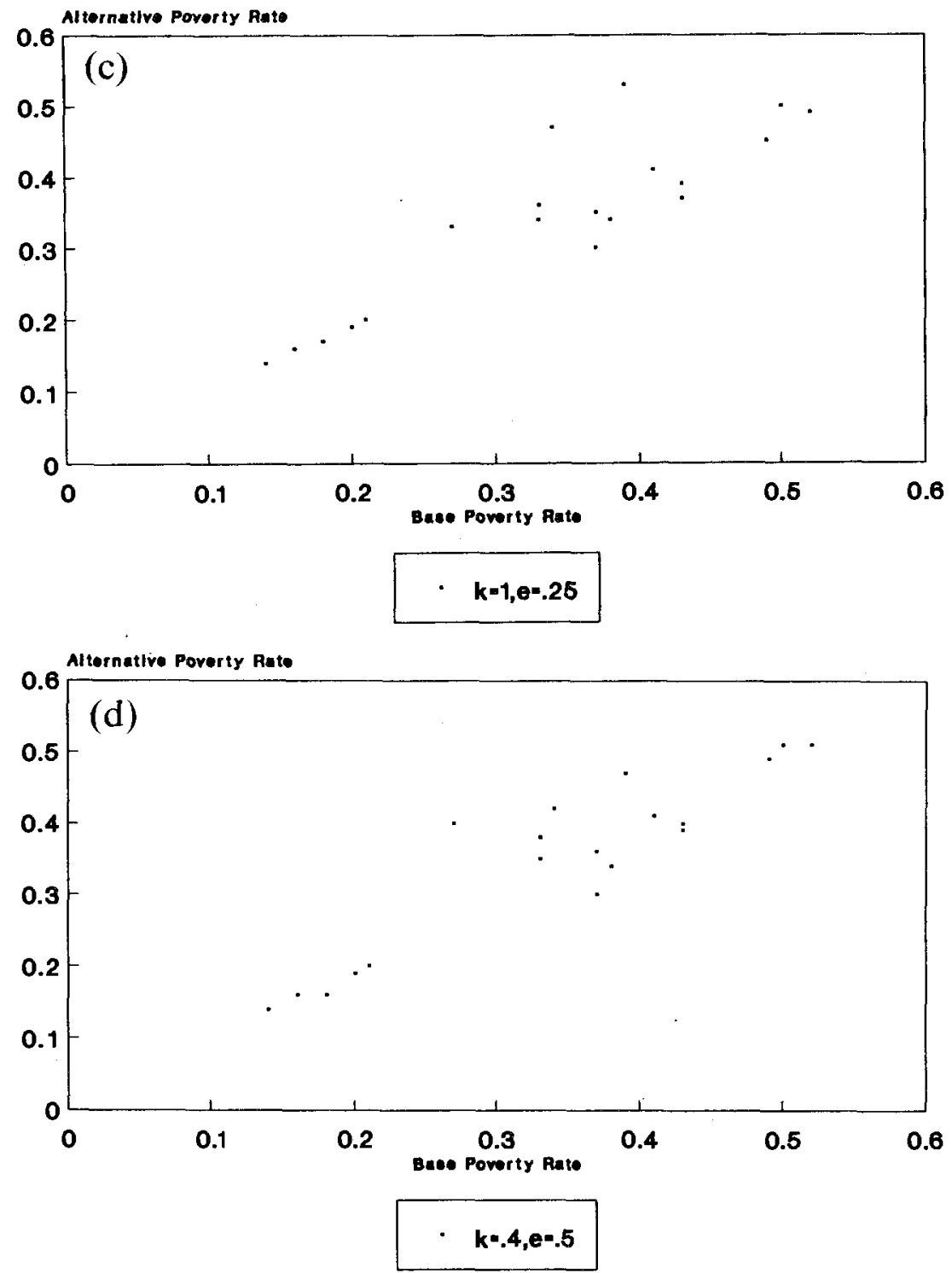

Motes, Camoinnt powerty line tor

Figure 3-continued

percentage of individuals in households headed by an unmarried female with children is 5 percent or less in most countries, but is 10 percent in the U.S.

There is considerable variation across countries in the percentage of individuals in households with no earners. This percentage is on average over 20 percent in Australia, Austria, Germany, the Netherlands, and the U.K., and is lowest in Canada and the U.S. (12 to 13 percent). There is less variation in the percentage of individuals in households with very young heads (though, as expected, Sweden is an outlier here). A few countries tend to have larger elderly-head components 

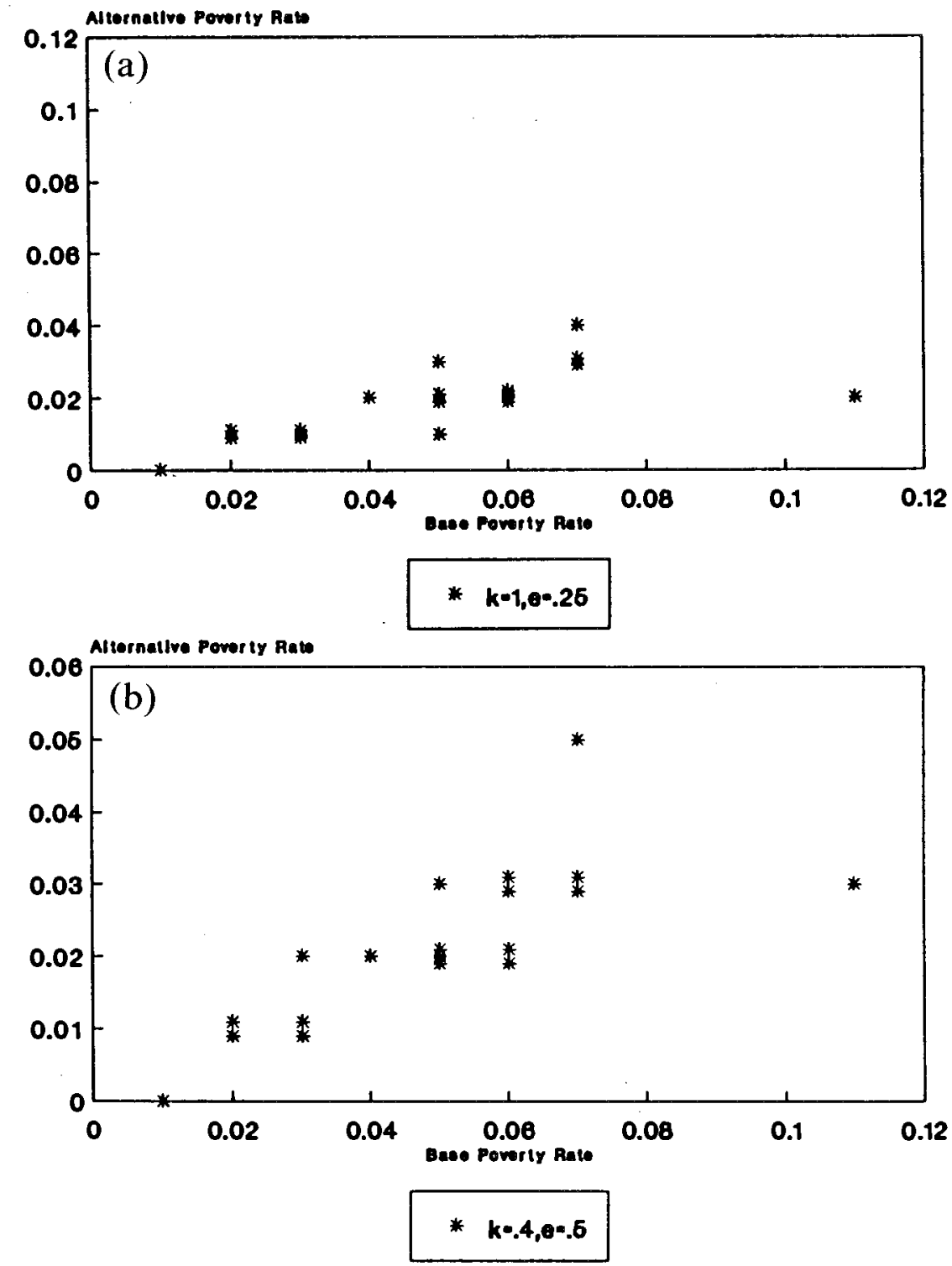

Neter Cenotent eoverty line wer

Figure 4. Extreme Poverty, Alternative Equivalence Scales

of the population-Austria, Germany, and Sweden are all around 20 percentbut most countries have around 12 percent of the population in elderly-headed households.

Table 6 reports percentages of individuals in various types of households that fall below the standard poverty lines. Countries with the lowest overall standard poverty rates differ from other countries mostly in their low poverty rates for married-couple households, and in particular married couples with children. Poverty rates for female-headed households are high in all countries, as are 

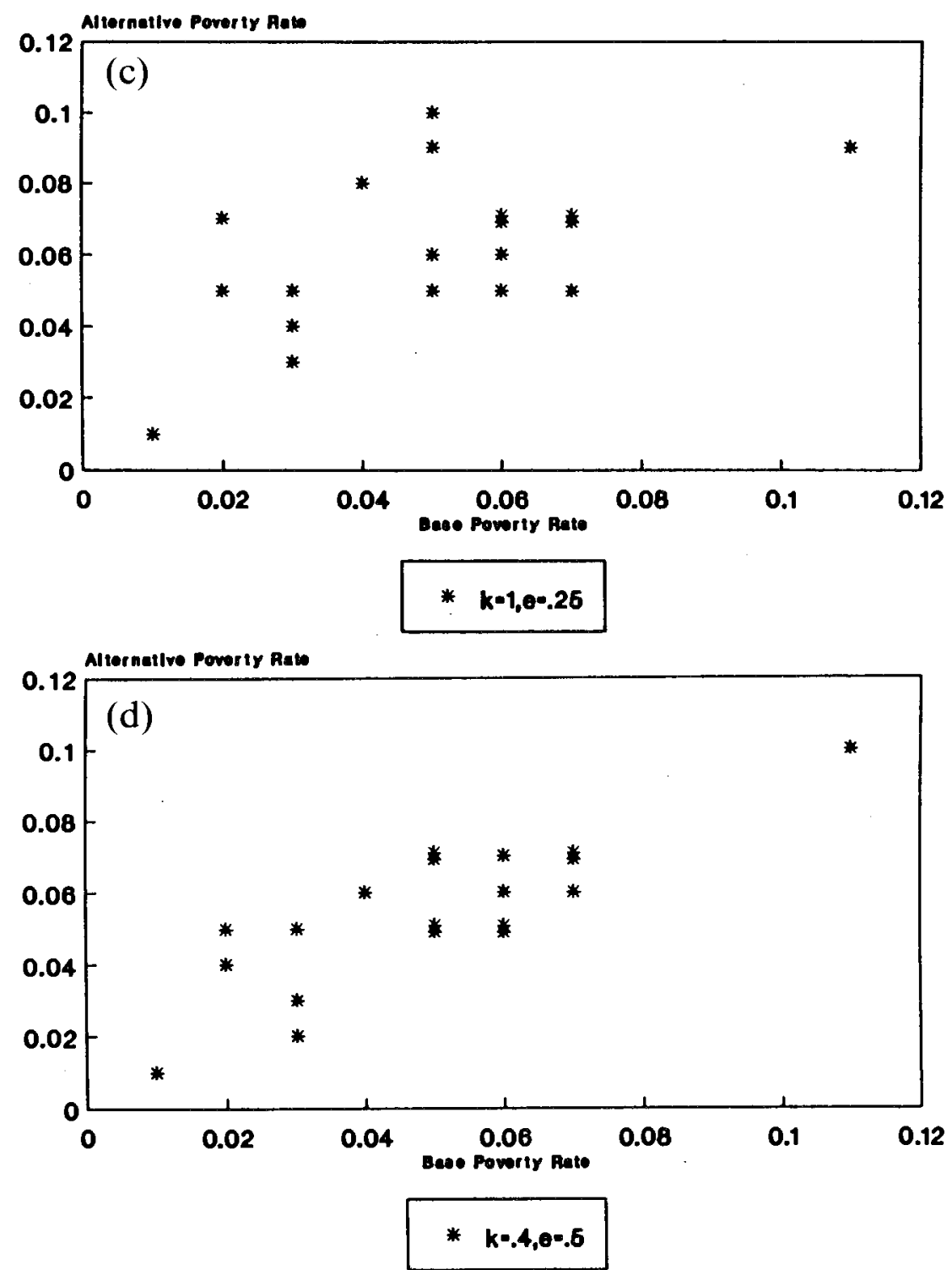

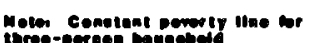

Figure 4 continued

poverty rates for households with no earners. Poverty rates for the elderly are substantially higher than overall poverty in some countries-Australia, Austria, Sweden, and the U.K.-but in other countries there is little difference.

Extreme poverty rates within types of households are reported in Table 7. As would be expected, extreme poverty rates are much lower than standard poverty rates in all household types. This is particularly true for female headed households, where extreme poverty rates are on average about 40 percentage points lower than standard rates; however, this type of household continues to have 

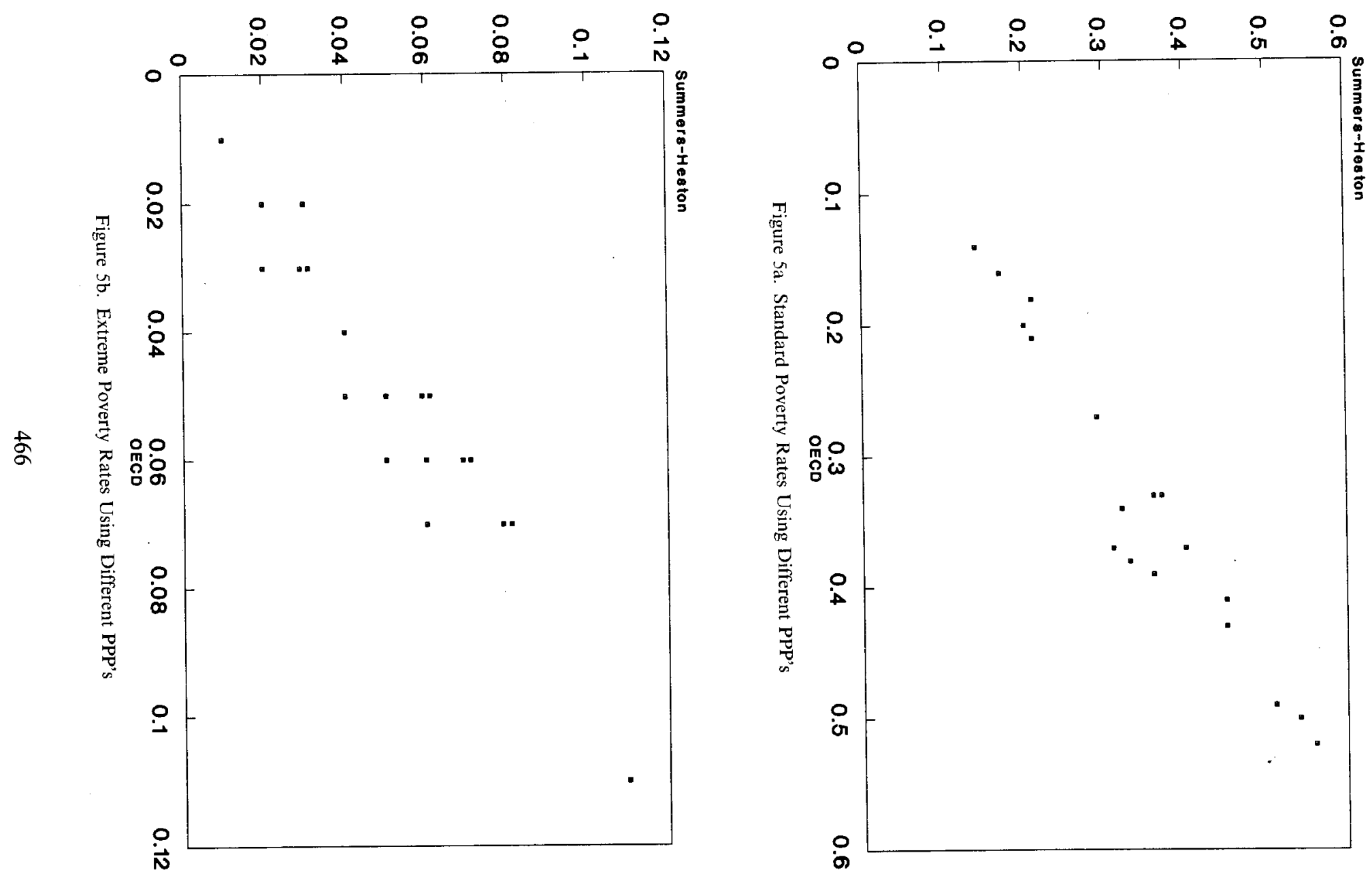
TABLE 5

Household Characteristics of Individuals in the LiS Samples

\begin{tabular}{|c|c|c|c|c|c|c|c|}
\hline \multirow[b]{4}{*}{ Country } & \multicolumn{7}{|c|}{ Percentage 1n } \\
\hline & \multirow[b]{3}{*}{ Year } & \multicolumn{2}{|c|}{ Married Couple } & \multirow{3}{*}{$\begin{array}{c}\text { Female } \\
\text { Head } \\
\text { With } \\
\text { Children }\end{array}$} & \multirow{3}{*}{$\begin{array}{c}\text { No. } \\
\text { Earnings' }\end{array}$} & \multirow{2}{*}{\multicolumn{2}{|c|}{ Head's Age }} \\
\hline & & With & No & & & & \\
\hline & & Children & Children & & & $<25$ & $>64$ \\
\hline \multicolumn{8}{|l|}{$1979-83$} \\
\hline Australia & $1981-2$ & 0.57 & 0.24 & 0.05 & 0.26 & 0.06 & 0.11 \\
\hline Canada & 1981 & 0.54 & 0.25 & 0.06 & 0.11 & 0.06 & 0.11 \\
\hline France & 1979 & 0.57 & 0.28 & 0.03 & 0.15 & 0.06 & 0.15 \\
\hline Germany & 1981 & 0.50 & 0.29 & 0.02 & 0.19 & 0.06 & 0.18 \\
\hline Netherlands & 1983 & 0.55 & 0.30 & 0.03 & 0.24 & 0.06 & 0.12 \\
\hline Sweden & 1981 & 0.41 & 0.26 & 0.05 & 0.17 & 0.08 & 0.19 \\
\hline United Kingdom & 1979 & 0.55 & 0.26 & 0.05 & 0.18 & 0.04 & 0.16 \\
\hline United States & 1979 & 0.50 & 0.24 & 0.10 & 0.12 & 0.07 & 0.13 \\
\hline \multicolumn{8}{|l|}{198487} \\
\hline Australia & $1985-86$ & 0.52 & 0.26 & 0.04 & 0.18 & 0.04 & 0.12 \\
\hline Austria $^{2}$ & 1987 & \multicolumn{2}{|c|}{0.70} & & 0.27 & 0.04 & 0.20 \\
\hline Canada & 1987 & 0.50 & 0.28 & 0.05 & 0.12 & 0.04 & 0.12 \\
\hline France & 1984 & 0.54 & 0.29 & 0.03 & 0.23 & 0.03 & 0.13 \\
\hline Germany & 1984 & 0.43 & 0.37 & 0.02 & 0.24 & 0.02 & 0.18 \\
\hline Italy & 1986 & 0.53 & 0.34 & 0.02 & 0.17 & 0.01 & 0.16 \\
\hline Luxembourg & 1985 & 0.52 & 0.31 & 0.03 & 0.18 & 0.03 & 0.13 \\
\hline Netherlands & 1987 & 0.50 & 0.30 & 0.04 & 0.26 & 0.04 & 0.13 \\
\hline Sweden & 1987 & 0.39 & 0.28 & 0.06 & 0.17 & 0.10 & 0.20 \\
\hline United Kingdom & 1986 & 0.48 & 0.30 & 0.06 & 0.28 & 0.04 & 0.16 \\
\hline United States & 1986 & 0.47 & 0.27 & 0.10 & 0.14 & 0.04 & 0.14 \\
\hline
\end{tabular}

Note: The reported statistics are (weighted) percentages of individuals living in households with the corresponding characteristic.

${ }^{1}$ Households in which no member received earnings over the relevant income period.

${ }^{2}$ Information on the number of children is not available for Austria. The reported number is for all married couples.

fairly high extreme poverty rates in Australia and the U.S. Extreme poverty rates for households with no earners are also much smaller than the standard rates, though again this is less true for Australia and the U.S. Since both of these types of households tend to rely heavily on government transfers, it would appear that there are universal transfer benefit programs for most countries that provide transfers that are generally above the extreme poverty lines but below the standard poverty lines. In Australia and the U.S., these programs would appear to be either less universal, or to have greater variation in the benefit levels within the country. ${ }^{25}$ Extreme poverty rates for the elderly are equal to or less than overall extreme poverty rates in all countries.

To what extent can cross-national differences in household characteristics account for differences in poverty rates? I made use of the decomposability of the headcount ratio to perform a simple shift-share analysis of the contribution of these household-related characteristics to cross-national differences in poverty. ${ }^{26}$

\footnotetext{
${ }^{25}$ For example, there is much cross-state variation in the level of AFDC and unemployment compensation benefits in the U.S., while the unemployment compensation program does not cover all low-income unemployed.

${ }^{26} \mathrm{~A}$ detailed accounting of these results is available from the author upon request.
} 
TABLE 6

Poverty Rates for Different Household Types: Standard Poverty Lines

\begin{tabular}{|c|c|c|c|c|c|c|c|}
\hline \multirow[b]{4}{*}{ Country } & \multirow[b]{4}{*}{ Year } & \multicolumn{6}{|c|}{ Percentage Poor In } \\
\hline & & \multicolumn{2}{|c|}{ Married Couple } & \multirow{3}{*}{$\begin{array}{l}\text { Female } \\
\text { Head } \\
\text { With } \\
\text { Children }\end{array}$} & \multirow{3}{*}{$\begin{array}{c}\text { No. } \\
\text { Earnings }\end{array}$} & \multirow{2}{*}{\multicolumn{2}{|c|}{ Head's Age }} \\
\hline & & With & No & & & & \\
\hline & & Children & Children & & & $<25$ & $>64$ \\
\hline \multicolumn{8}{|l|}{$\overline{1979-83}$} \\
\hline Australia & $1981-2$ & 0.40 & 0.24 & 0.69 & 0.65 & 0.31 & 0.58 \\
\hline Canada & 1981 & 0.15 & 0.06 & 0.50 & 0.41 & 0.24 & 0.16 \\
\hline France & 1979 & 0.49 & 0.29 & 0.69 & 0.51 & 0.43 & 0.42 \\
\hline Germany & 1981 & 0.42 & 0.21 & 0.42 & 0.46 & 0.23 & 0.36 \\
\hline Netherlands & 1983 & 0.65 & 0.34 & 0.75 & 0.62 & 0.58 & 0.46 \\
\hline Sweden & 1981 & 0.46 & 0.28 & 0.64 & 0.56 & 0.40 & 0.52 \\
\hline United Kingdom & 1979 & 0.46 & 0.31 & 0.67 & 0.84 & 0.48 & 0.67 \\
\hline United States & 1979 & 0.17 & 0.09 & 0.60 & 0.49 & 0.28 & 0.24 \\
\hline \multicolumn{8}{|l|}{$1984-87$} \\
\hline Australia & $1985-6$ & 0.40 & 0.31 & 0.76 & 0.83 & 0.34 & 0.64 \\
\hline Austria' & 1987 & \multicolumn{2}{|c|}{0.22} & & 0.44 & 0.33 & 0.40 \\
\hline Canada & 1987 & 0.15 & 0.05 & 0.47 & 0.30 & 0.26 & 0.07 \\
\hline France & 1984 & 0.44 & 0.26 & 0.68 & 0.48 & 0.42 & 0.32 \\
\hline Germany & 1984 & 0.43 & 0.19 & 0.76 & 0.43 & 0.49 & 0.34 \\
\hline Italy & 1986 & 0.56 & 0.39 & 0.61 & 0.68 & 0.75 & 0.53 \\
\hline Luxembourg & 1985 & 0.24 & 0.10 & 0.35 & 0.26 & 0.25 & 0.19 \\
\hline Netherlands & 1987 & 0.64 & 0.28 & 0.91 & 0.63 & 0.58 & 0.45 \\
\hline Sweden & 1987 & 0.34 & 0.21 & 0.60 & 0.56 & 0.50 & 0.50 \\
\hline United Kingdom & 1986 & 0.47 & 0.28 & 0.78 & 0.71 & 0.48 & 0.50 \\
\hline United States & 1986 & 0.20 & 0.08 & 0.61 & 0.45 & 0.37 & 0.20 \\
\hline
\end{tabular}

'Information on the number of children is not available for Austria. The reported number is for all married couples.

The analysis is based on a separation of each country's household population into 72 groups, defined on the interactions of the age of the household head, head's marital status and sex, presence of children under 18 , and number of earners. For the most part, little of the poverty-rate difference between the U.S. and other countries is explained by differences in population characteristics between these countries. The major exception is Canada, where about half of the lower standard poverty rate in Canada can be accounted for by these differences (in particular, the lower rate of female headness in Canada).

\section{Concluding Remarks}

Any study of poverty is hampered by the lack of agreement over an appropriate definition and method for measurement of the degree of poverty in a society. Even with the assumption that annual income is an appropriate gauge of economic well-being, there remain several issues associated with deciding who is poor, and how the poverty status of all individuals can be represented in a simple form that can be compared across countries. Using data from the Luxembourg Income Study, I have found that cross-national comparisons of income poverty among developed economies can be quite sensitive to the precise manner in which poverty is measured. 
TABLE 7

Poverty Rates for Different Household Types: 50\% of Standard Poverty Lines

\begin{tabular}{|c|c|c|c|c|c|c|c|}
\hline \multirow[b]{4}{*}{ Country } & \multirow[b]{4}{*}{ Year } & \multicolumn{6}{|c|}{ Percentage Poor ln } \\
\hline & & \multicolumn{2}{|c|}{ Married Couple } & \multirow{3}{*}{$\begin{array}{c}\text { Female } \\
\text { Head } \\
\text { With } \\
\text { Children }\end{array}$} & \multirow{3}{*}{$\begin{array}{c}\text { No. } \\
\text { Earnings }^{\prime}\end{array}$} & \multirow{2}{*}{\multicolumn{2}{|c|}{ Head's Age }} \\
\hline & & With & No & & & & \\
\hline & & Children & Children & & & $<25$ & $>64$ \\
\hline \multicolumn{8}{|l|}{$1979-83$} \\
\hline Australia & 1981-2 & 0.06 & 0.02 & 0.30 & 0.17 & 0.07 & 0.03 \\
\hline Canada & 1981 & 0.03 & 0.01 & 0.13 & 0.10 & 0.08 & 0.01 \\
\hline France & 1979 & 0.07 & 0.05 & 0.21 & 0.08 & 0.09 & 0.03 \\
\hline Germany & 1981 & 0.02 & 0.03 & 0.02 & 0.07 & 0.03 & 0.05 \\
\hline Netherlands & 1983 & 0.07 & 0.05 & 0.08 & 0.09 & 0.21 & 0.03 \\
\hline Sweden & 1981 & 0.04 & 0.01 & 0.08 & 0.05 & 0.14 & 0.00 \\
\hline United Kingdom & 1979 & 0.07 & 0.01 & 0.16 & 0.16 & 0.11 & 0.01 \\
\hline United States & 1979 & 0.04 & 0.02 & 0.23 & 0.19 & 0.07 & 0.04 \\
\hline \multicolumn{8}{|l|}{$1984-87$} \\
\hline Australia & $1985-6$ & 0.08 & 0.04 & 0.33 & 0.20 & 0.13 & 0.04 \\
\hline Austria $^{1}$ & 1987 & \multicolumn{2}{|c|}{0.00} & & 0.04 & 0.06 & 0.02 \\
\hline Canada & 1987 & 0.02 & 0.01 & 0.10 & 0.07 & 0.07 & 0.01 \\
\hline France & 1984 & 0.05 & 0.04 & 0.15 & 0.13 & 0.07 & 0.01 \\
\hline Germany & 1984 & 0.02 & 0.02 & 0.19 & 0.06 & 0.12 & 0.03 \\
\hline Italy & 1986 & 0.13 & 0.07 & 0.18 & 0.18 & 0.26 & 0.11 \\
\hline Luxembourg & 1985 & 0.01 & 0.01 & 0.01 & 0.02 & 0.06 & 0.00 \\
\hline Netherlands & 1987 & 0.06 & 0.02 & 0.10 & 0.10 & 0.24 & 0.00 \\
\hline Sweden & 1987 & 0.03 & 0.01 & 0.04 & 0.03 & 0.20 & 0.01 \\
\hline United Kingdom & 1986 & 0.10 & 0.03 & 0.11 & 0.14 & 0.10 & 0.01 \\
\hline United States & 1986 & 0.05 & 0.02 & 0.27 & 0.18 & 0.15 & 0.03 \\
\hline
\end{tabular}

'Information on the number of children is not available for Austria. The reported number is for all married couples.

In my analysis, the most significant definitional decision in measuring poverty is the choice between using a relative or absolute sense of poverty. Countries that have higher levels of inequality, such as Australia, Canada, Italy, and the U.S., also tend to have high levels of relative poverty. However, some high-inequality countries (e.g. Canada and the U.S.) also tend to have high average incomes, and these countries tend to have low absolute poverty rates. Absolute poverty comparisons are also sensitive to proportional changes in the real value of the poverty lines. Canada, Luxembourg, and the U.S. have considerably lower poverty rates than the other countries when the poverty lines are such that about 20 percent of the U.S. population is counted as poor. However, if these poverty lines were cut in half (leaving about 5 percent of the U.S. population poor), almost all countries have absolute poverty rates that are close to, or lower than, the U.S. poverty rate. The presence of extreme poverty measured in this way is much more related to the dispersion of the income distribution than poverty comparisons at more usual magnitudes for the poverty lines.

Is absolute poverty or relative poverty a more appropriate concept for international comparisons? Measures based on these two concepts are measuring different things. Relative poverty is basically a manifestation of the level of inequality of incomes, where attention is concentrated on the low end of the distribution. An absolute poverty measure can be argued to incorporate a social 
welfare comparison across countries, related to but not solely dependent upon the level of inequality. To say that one country has a higher level of relative poverty than another does not tell the complete story about well-being comparisons of individuals at the low end of the distribution.

There are several criticisms that could be made of the poverty comparisons in this paper. I have attempted to be careful that the basic conclusions are not sensitive to certain measurement choices, namely the equivalence scales and the purchasing power parities. However, there are other potential problems that I am unable to address. This study assumes that the LIS disposable income series is internationally comparable. Much work has gone into constructing the LIS database so as to make it truly comparable, and I am unaware of any other data source that would be better for the type of analysis of this paper. However, there may be certain intangibles that are not easily incorporated into a quantitative measure of poverty: government benefits that are neither cash nor near-cash benefits; or conditions within low-income communities, such as crime, violence, or cleanliness, that more severely affect the poor in some countries. A cross-national comparison of poverty that includes these intangibles requires a more imaginative accounting than is customarily used in studies of poverty.

\section{APPENDIX}

In this appendix, I extend the work of Cowell (1989) to provide standard error formulas for estimates of poverty rates. These formulas treat both poverty status of the household and the household weight as random variables.

A weighted poverty rate is calculated using the formula

$$
p=\Sigma v_{i} m_{i} d_{i} / \Sigma v_{i} m_{i}=\Sigma w_{i} d_{i} / \Sigma w_{i}=x / y,
$$

where $m_{i}$ is the number of persons in the household, $v_{i}$ is the population weight for that household, $d_{i}$ is a dummy variable equal to one if the household is poor, $w_{i}=v_{i} m_{i}, x$ is the sample mean of the product of $w$ and $d$, and $y$ is the sample mean of $w$. This can be thought of as a method of moments estimator of the population quantity

$$
P=E(w d) / E(w),
$$

where $P$ is the expected number of people in poverty per household, divided by the expected number of people per household. $P$ is a function of moments of $w$ and $d$, so the delta method can be used to derive the asymptotic variance of $p$, that is,

$$
A V(p)=V(x) / y^{2}+x^{2} V(y) / y^{4}-2 x \operatorname{cov}(x, y) / y^{3} .
$$

Assuming independent and identically distributed observations, $p$ will be asymptotically normal with variance $A V(p)$. This asymptotic variance can be estimated using the usual sample formulas for $V(x)$ and $V(y) ; \operatorname{cov}(x, y)=\operatorname{cov}(w d, w) / n$ under an i.i.d. assumption, which can be estimated using the sample analog to $\operatorname{cov}(w d, w)$. 
TABLE A.1

Purchasing Power Parities and Alternative Income Measures

\begin{tabular}{|c|c|c|c|c|c|}
\hline \multirow[b]{2}{*}{ Country } & \multirow[b]{2}{*}{ Year } & \multicolumn{2}{|c|}{ PPP/Inflation Factors ${ }^{1}$} & \multicolumn{2}{|c|}{ Per Capita Averages ${ }^{2}$} \\
\hline & & OECD & $\mathrm{S}-\mathrm{H}$ & LIS-DY & Priv. Cons. \\
\hline \multicolumn{6}{|l|}{197983} \\
\hline Australia & $1981-2$ & 1.034 & 1.128 & 5,737 & 6,565 \\
\hline Canada & 1981 & 1.034 & 1.009 & 8,378 & 7,977 \\
\hline France & 1979 & 0.238 & 0.229 & 5,447 & 6,785 \\
\hline Germany & 1981 & 0.443 & 0.431 & 5,856 & 6,597 \\
\hline Netherlands & 1983 & 0.418 & 0.401 & 4,841 & 6,617 \\
\hline Sweden & 1981 & 0.155 & 0.158 & 5,302 & 6,149 \\
\hline United Kingdom & 1979 & 2.825 & 2.771 & 5,136 & 6,533 \\
\hline United States & 1979 & 1.482 & 1.482 & 8,204 & 10,238 \\
\hline \multicolumn{6}{|l|}{$1984-87$} \\
\hline Australia & $1985-86$ & 0.772 & 0.842 & 5,934 & 6,972 \\
\hline Austria & 1987 & 0.055 & 0.053 & 5,949 & 6,190 \\
\hline Canada & 1987 & 0.748 & 0.730 & 8,621 & 9,528 \\
\hline France & 1984 & 0.141 & 0.135 & 5,837 & 7,087 \\
\hline Germany & 1984 & 0.399 & 0.387 & 5,767 & 6,824 \\
\hline Italy & 1986 & 0.702 & 0.682 & 4,835 & 6,938 \\
\hline Luxembourg & 1985 & 0.023 & 0.022 & 7,019 & 8,062 \\
\hline Netherlands & 1987 & 0.399 & 0.382 & 5,055 & 7,067 \\
\hline Sweden & 1987 & 0.104 & 0.106 & 5,596 & 6,889 \\
\hline United Kingdom & 1986 & 1.636 & 1.541 & 5,588 & 7,096 \\
\hline United States & 1986 & 0.981 & 0.981 & 8,999 & 11,330 \\
\hline
\end{tabular}

'The factors are multiplied by incomes in the listed country/year's currency to obtain incomes in SUS in 1985. "OECD" uses the purchasing power parities for private final consumption in 1985 (SNA classification), provided by OECD (1989). "S-H" uses the purchasing power parities for consumption expenditures in 1985 suggested by Summers and Heston (1991). Within-country price level changes are measured using the consumer price indices reported in the International Monetary Fund (1991).

2"LIS-DY" is per capita disposable income from the LIS. "Priv. Cons." is private final consumption per head as reported in OECD (1989), corrected for price changes using the U.S. Consumer Price Index.

\section{REFERENCES}

Atkinson, A. B., The Economics of Inequality, Oxford University Press, Oxford, 1983. , On the Measurement of Poverty, Econometrica, 55, 749-64, July, 1987.

Blackburn, M. L., Trends in Poverty in the U.S., 1967-84, Review of Income and Wealth, 36, 53 66, March, 1990.

-, International Comparisons of Poverty, American Economic Review, 84, 371-4, May, 1994.

Buhmann, B., L. Rainwater, G. Schmaus, and T. M. Smeeding, Equivalence Scales, Well-Being, Inequality, and Poverty: Sensitivity Estimates Across 'Ten Countries Using the Luxembourg Income Study (LIS) Database, Review of Income and Wealth, 34, 115-42, June, 1988.

Cowell, F. A., Sampling Variance and Decomposable Inequality Measures, Journal of Econometrics, 42, 27-41, October, 1989.

Cutler, D. M. and L. F. Katz, Rising Inequality? Changes in the Distribution of Income and Consumption in the 1980s, American Economic Review, 82, 546-51, May 1992.

Ellwood, D. T. and L. H. Summers, Poverty in America: Is Welfare the Answer or the Problem? in S. Danziger and D. Weinberg, (eds.), Fighting Poverty: What Works and What Doesn't, 78-105, Harvard University Press, Cambridge, MA, 1986.

Foster, J. E., J. Greer, and E. Thorbecke, A Class of Decomposable Poverty Measures, Econometrica, 52, 761-6, May, 1984.

Garfinkel, I. and S. S. McLanahan, Single Mothers and their Children: A New American Dilemma, Urban Institute Press, Washington, DC, 1986.

Hanratty, M. and R. Blank, Down and Out in North America: Recent Trends in Poverty Rates in the U.S. and Canada, Quarterly Journal of Economics, Vol. 57, 233-54, February 1990. 
International Monetary Fund, International Financial Statistics, 44, International Monetary Fund, Washington, DC, I991.

Mayer, S. E., A Comparison of Poverty and Living Conditions in Five Countries, Institute for Research on Poverty Discussion Paper no. 987-92, Madison, Wisconsin, 1992.

Mitchell, D., Income Transfers in Ten Welfare States, Avebury, Aldershot, England, 1991.

Organization for Economic Co-operation and Development, National Accounts: Main Aggregates, 1960-87, OECD, Paris, 1989.

Smeeding, T. M., L. Rainwater, M. Rein, R. Hauser, and G. Schaber, Income Poverty in Seven Countries: Initial Estimates from the LIS Database, in T. M. Smeeding, M. O'Higgins, and L. Rainwater (eds.), Poverty, Inequality, and Income Distribution in Comparative Perspective: The Luxembourg Income Study (LIS), 57-76, Urban Institute Press, Washington, DC, 1990.

and G. Schmaus, The LIS Database: Technical and Methodological Aspects, in T. M. Smeeding, M. O'Higgins, and L. Rainwater (eds.), Poverty, Inequality, and Income Distribution in Comparative Perspective: The Luxembourg Income Study (LIS), 1-19, Urban Institute Press, Washington, DC, 1990.

and B. Boyd Torrey, Poor Children in Rich Countries, Science, 242, 873-77, November 11, 1988.

Summers, R. and A. Heston, The Penn World Table (Mark 5): An Expanded Set of International Comparisons, 1950-88, Quarterly Journal of Economics, 106, 327-68, May, 1991. 